\title{
Liming and Phosphating in Dalbergia nigra (Vell.) Allemão ex Benth. Seedlings
}

\author{
Leandro Carlos ${ }^{1}$, Nelson Venturin ${ }^{2}$, Regis Pereira Venturin ${ }^{3}$, José Milton Alves ${ }^{1}$, \\ Patrícia Oliveira da Silva ${ }^{1}$
}

${ }^{1}$ Programa de Pós-graduação em Ciências Agrárias, Departamento de Agronomia, Instituto Federal Goiano - IFGoiano, Rio Verde/GO, Brasil

${ }^{2}$ Programa de Pós-graduação em Engenharia Florestal, Departamento de Ciências Florestais, Universidade Federal de Lavras - UFLA, Lavras/MG, Brasil

${ }^{3}$ Empresa de Pesquisa Agropecuária de Minas Gerais - EPAMIG, Lavras/MG, Brasil

\begin{abstract}
This study aimed to verify the effect of phosphorus and liming doses on the morphological and nutritional characteristics of $D$. nigra seedlings. The experiment was conducted using a completely randomized $4 \times 4$ factorial design. The treatments consisted of 4 levels of liming and 4 phosphorus doses. Morphological characteristics and nutritional analyses of plants were measured. There were no significant interactions between liming x P. Morphological characteristics presented differences for liming and phosphorus when analyzed separately. The best productive performances were found between an increase in base saturation between $48.07 \%$ and $54.76 \%$. Morphological characteristics showed a linear behavior for P. Both the application of liming and P promoted positive effects on D. nigra growth.
\end{abstract}

Keywords: seedling quality, forest nutrition, jacarandá-da-bahia. 


\section{INTRODUCTION}

Bahia rosewood (Dalbergia nigra (Vell.) Allemão ex Benth.) is a Fabaceae classified as late secondary, naturally occurring in low fertility soils in regions of the Atlantic Forest. It presents moderate to rapid growth under adequate growth conditions. Its wood is of good quality, with a pleasant appearance and is recommended for making luxury furniture. The species can be used for landscaping of public squares, parks and avenues, and it is recommended for soil recovery, for performing biological nitrogen fixation, depositing a reasonable layer of leaves and presenting a wide range of environmental tolerance (Carvalho, 2003).

Several studies with forest species have demonstrated that the fertilization of several species improves the productivity, quality and establishment of forest plantations. However, considering the great diversity in Brazil, scientific studies on nutritional requirements of native forest species are still scarce.

One way to assess nutritional requirements would be to determine optimal fertilization rates for the various soil types. In this context, Macedo \& Teixeira (2012) and Silva et al. (2011) studied saturation by bases and $\mathrm{P}$ doses for araçá-boi (Eugenia stipitata) and mahogany seedlings (Swietenia macrophilla) respectively, and the species showed positive responses to the use of these fertilizers. Bernardino et al. (2007) showed that a Ca:Mg ratio for Latosol of 4:1 presented superior results in height, diameter, and dry matter for $D$. nigra.

The development of silvicultural techniques for wood species such as jacaranda-da-bahia (Dalbergia nigra) is necessary given the intense exploitation that has occurred throughout national history, driving its population to low levels. Therefore, one solution is to learn about the forestry of these species. There is a need to improve technology for growing forest species seedlings, and within this context knowledge about the nutritional demands of the species used for these purposes and others is of fundamental importance (Fernandes et al., 2000). In this sense, this study aimed to verify the effect of phosphorus and liming doses on the morphological and nutritional characteristics of D. nigra seedlings in a greenhouse, using a Dystrophic Red Latosol/typic haplustox soil as substrate.

\section{MATERIAL AND METHODS}

The study was conducted under controlled conditions in the Department of Forestry Sciences of the Federal University of Lavras-UFLA and lasted 8 months. A Dystrophic Red Latosol/typic haplustox soil of low natural fertility was used as substrate. The soil was collected from the municipality of Lavras, MG, at a depth of 20 to $40 \mathrm{~cm}$, avoiding the fertile soil layer that could mask the effect of fertilizers. The soil was air-dried and sieved using $2 \mathrm{~mm}$ mesh sieves, and a sample was then taken for physical and chemical analysis. Next, $4.5 \mathrm{dm}^{3}$ of soil were deposited in pots with a capacity of $4.8 \mathrm{dm}^{3}$, then the appropriate soil liming was performed at that moment and incubated for a period of twenty days for the fertilizer to react with the soil. Solutions containing the other treatments were then applied after the incubation period, and the pots had their bottoms sealed to prevent nutrient loss. Finally, soil samples were taken after fertilization of the treatments to verify their efficacy.

The experimental design was completely randomized in a factorial scheme with four levels of liming and four $\mathrm{P}$ doses of four replications. The liming treatments were as follows: 1) natural base saturation (V\%) of the soil (23.2\%) (meaning without liming); 2) dose for V (\%) elevation to $45 \%$, or application of 0.52 tons per hectare; 3) dose for $V(\%)$ elevation to $65 \%$, or application of 1 ton per hectare; 4) dose for $\mathrm{V}(\%)$ elevation to $85 \%$, or application of 1.6 tons per hectare. The phosphorus treatments (P) were: $0,100,300$ and $500 \mathrm{mg} \mathrm{kg}^{-1}$.

Soil remediation was calculated based on $\mathrm{CaCO}_{3}$ and then applied in a Ca:Mg ratio of 4:1 using $\mathrm{CaCO}_{3}$ and $\mathrm{MgO}$ as sources. MAP, and $\mathrm{H}_{3} \mathrm{PO}_{4}$ were used as sources of $\mathrm{P}$, and $\mathrm{N}$ was balanced using urea so that the doses were equivalent. The nutrients were calculated based on the basic fertilization of each treatment, and applied as described by Carlos et al. (2015): $180 \mathrm{mg} \mathrm{kg}^{-1}$ of $\mathrm{N} ; 150 \mathrm{mg} \mathrm{kg}^{-1}$ of K; $40 \mathrm{mg} \mathrm{kg}^{-1}$ of S; $1.33 \mathrm{mg} \mathrm{kg}^{-1}$ of Cu; $0.81 \mathrm{mg} \mathrm{kg}^{-1}$ of B; $4 \mathrm{mg} \mathrm{kg}^{-1}$ of $\mathrm{Zn}$ and $0.15 \mathrm{mg} \mathrm{kg}^{-1}$ of Mo.

Descriptive soil analyses were performed for all treatments consisting of: texture determination (Densimeter Method) and particle density (Volumetric Balloon Method). The chemical analyses were realized according to the following methods: $\mathrm{pH}\left(\mathrm{H}_{2} \mathrm{O}\right.$ - Ratio 1:2.5); organic matter (Walkley \& Black method); $\mathrm{P}$ and 
$\mathrm{K}\left(\mathrm{HCl} 0.05\right.$ molc $\left.\mathrm{L}^{-1}+\mathrm{H}_{2} \mathrm{SO}_{4} 0.025 \mathrm{molc} \mathrm{L}^{-1}\right) ; \mathrm{Ca}$, $\mathrm{Mg}, \mathrm{Al}$ and $\mathrm{H}+\mathrm{Al}$ (extractor $\mathrm{KCl} 1$ molc $^{-1}$ ); $\mathrm{Zn}$, $\mathrm{Cu}, \mathrm{Fe}$ and $\mathrm{Mn}\left(\mathrm{HCl} 0.05 \mathrm{~mol}+\mathrm{H}_{2} \mathrm{SO}_{4} 0.25 \mathrm{~mol}\right.$ $\left.\mathrm{L}^{-1}\right) ; \mathrm{S}\left(\mathrm{Ca}\left(\mathrm{H}_{2} \mathrm{PO}_{4}\right) \cdot \mathrm{H}_{2}+500 \mathrm{ppm} \mathrm{P}\right) ; \mathrm{B}$ (hot water), according to Embrapa (1997).

These analyses were performed in the Laboratory of the Department of Soil Science of the Federal University of Lavras (UFLA), and the results are presented in Table 1.

Dalbergia nigra seeds were collected from the Rio Doce State Park, administered by the State Forest Institute of Minas Gerais. After collection, the seeds were taken to Lavras, benefited, and stored in a cold room. The seeds were germinated at the beginning of the experiment according to the methodology proposed by Andrade et al. (2006), at constant temperatures between 20 and $30^{\circ} \mathrm{C}$ and using vermiculite as substrate. The seeds were then transplanted into the treatment pots after radicle protrusion with one seedling planted per pot.

Soil moisture was maintained around $60 \%$ of the total pore volume (TPV) throughout the experiment and checked daily by weighing and completing the weight with deionized water. The experiment was terminated after 240 days when the pots were disassembled and the roots separated from the soil by rinsing under running water, thus obtaining whole and individualized plants. The biometric characteristics and their relationships considered for evaluating the seedlings were: shoot height in centimeters $(\mathrm{H})$; neck diameter in millimeters (D); shoot dry matter (DMS) and root dry matter (DMR) in grams; root dry mass and shoot dry mass (R/S); height/diameter (H/D) and Dickson quality index (DQI) (Dickson et al., 1960).

$\mathrm{P}$ contents were determined by colorimetry according to the nitric-perchloric extract, as well as $\mathrm{Ca}$ and $\mathrm{Mg}$ levels by atomic absorption spectrophotometry (Malavolta et al., 1997).

Data were submitted to analysis of variance and Scott-Knott's test at $5 \%$ probability to compare the means between treatments according to Gomes (1985). Regression analyses were generated for the dose experiments in order to determine the dose with the best growth using the Sisvar 4.6 program (Ferreira, 2011). Charts and tables were generated by the Microsoft Excel 2003 program.

\section{RESULTS AND DISCUSSION}

\subsection{Growth}

The analysis of variance showed no significant interactions between liming and phosphorus for any variable studied at 5\% significance. Macedo \& Teixeira (2012) found similar results to those of this study in studying the interaction of these same elements in araçá-boi (Eugenia stipitata), since the authors also found that there was no interaction between the variables.

On the other hand, the liming factor in this study showed differences at $5 \%$ significance for the variables of: diameter and height; shoot, root, and total dry matter; and Dickson quality index for the seedlings. Silva et al. (2008) also found similar results to those of this study in Sumaúma (Ceiba pentandra), which is not uncommon considering that several other species respond to liming; among these being: cássia-verrugosa/senna (Senna multijuga), ipê-mirim (Stenolobium stans), angico-do-cerrado (Anadenathera falcata), and cedar (Cedrela fissilis) (Furtini et al., 1999). Some other species are tolerant to acidity and do not respond to liming, with acacia (Acacia auriculiformes) and jacarandá-branco (Platipodium elegans) being examples (Mann et al., 1996).

The greatest diameter value in the liming experiment occurred in the base saturation of $51.76 \%$, which is equivalent to 0.69 tons of limestone per hectare (Figure 1). The height growth for D. nigra showed a similar trend as the diameter growth, although the highest growth was observed for base saturation of $48.07 \%$, or 0.61 tons per hectare. Tucci et al. (2010) corroborate the results obtained in this study, finding that limestone doses above $0.5 \mathrm{t} \mathrm{ha}^{-1}$ in balsa trees (Ochroma lagopus) increased base saturation to $40.21 \%$. This is similar to what was observed in the present study, as limestone can contribute to increased growth of seedling height and stem diameter.

TDM, DMS and DMR data presented their highest values for the limestone doses required to bring base saturation to $53.64,54.26$ and $54.76 \%$, respectively; or $0.75,0.77$ and 0.78 ton/ha (Figure 1). Macedo \& Teixeira (2012) concluded that the addition of dolomitic limestone to the substrate influenced growth and dry matter production in araçá-boi (Eugenia stipitata), showing that a dose equivalent to elevating the base saturation to $47.6 \%$ 


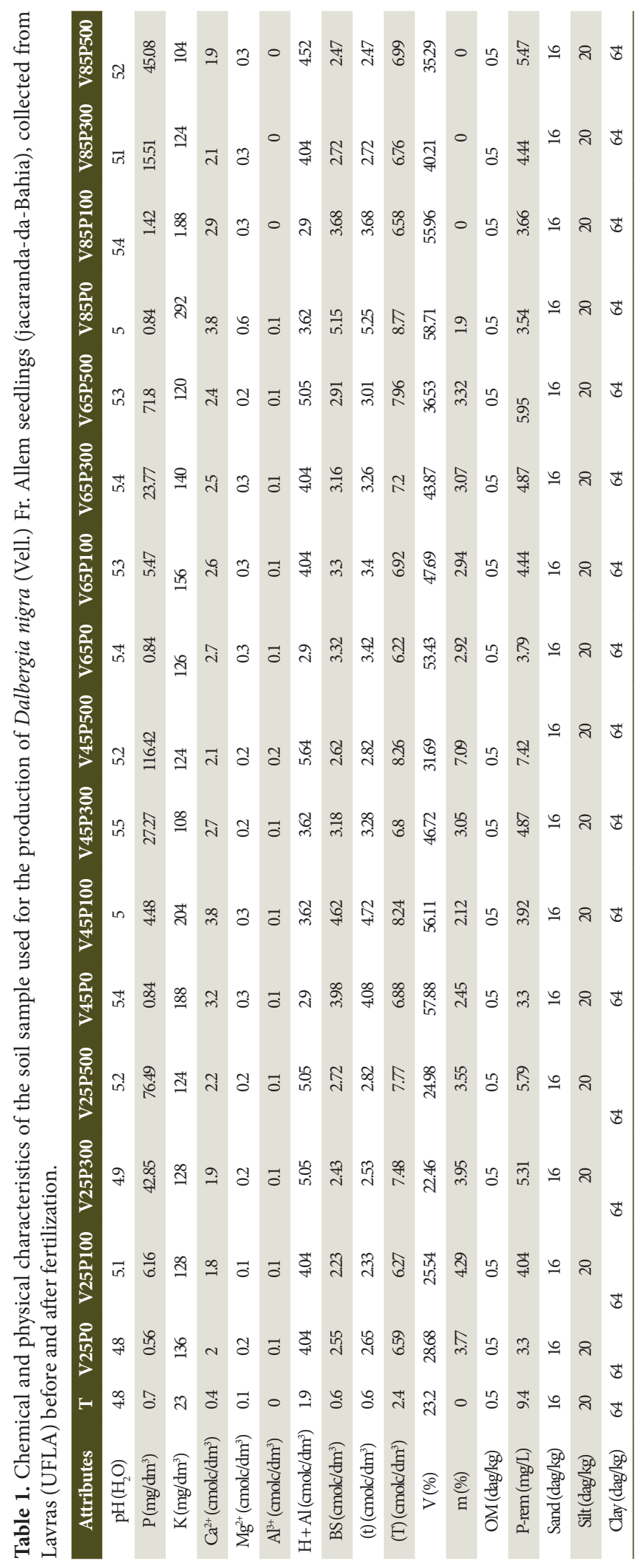



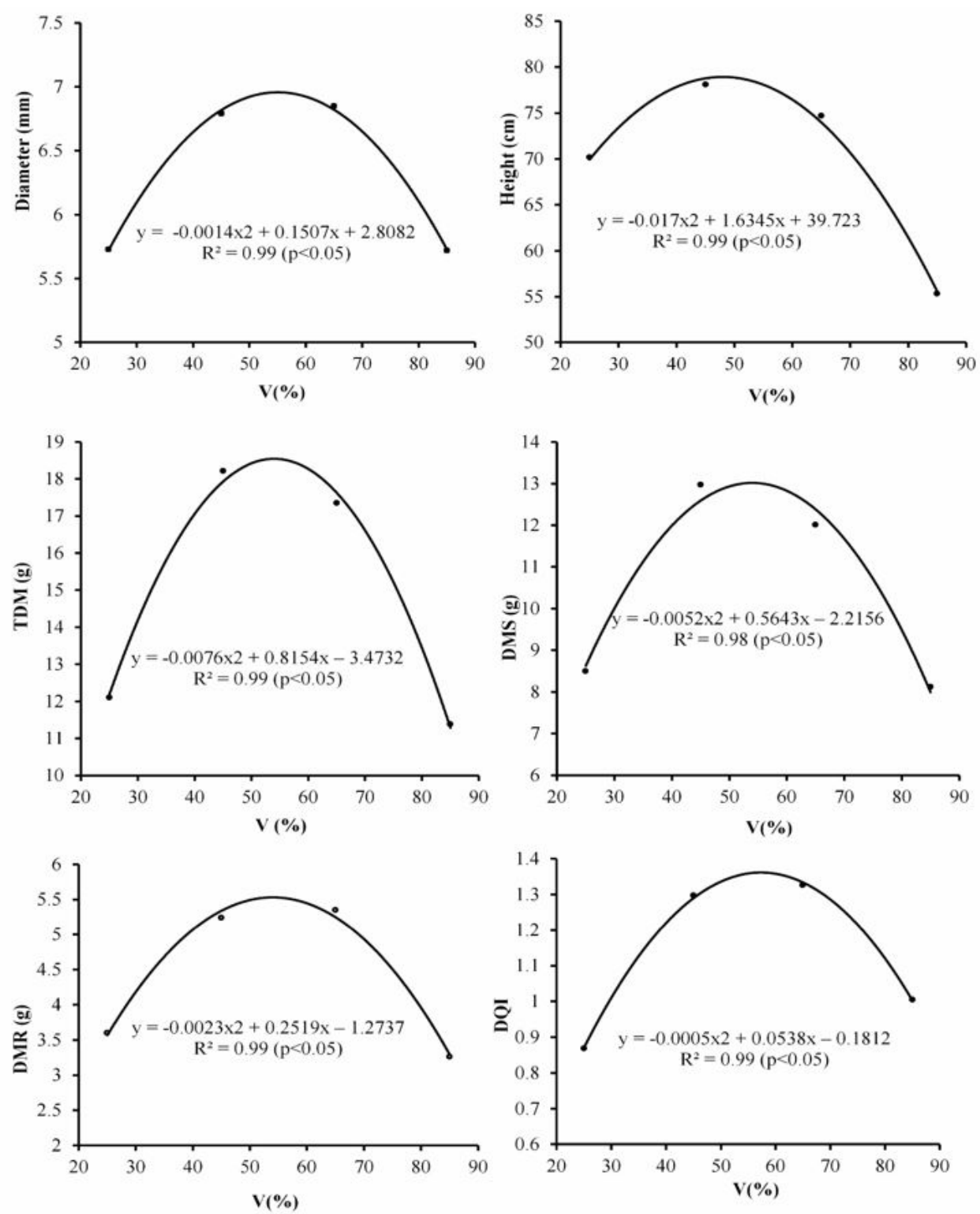

Figure 1. Diameter, height, total dry matter, shoot and root dry matter (TDM, DMS, DMR) and DQI for D. nigra seedlings of 240 days under different base saturations.

presented better seedling development. Gomes et al. (2008) recommend an increase of base saturation greater than (60\%) for garapa (Apuleia leiocarpa), since the highest production of DMS was obtained at this level. In studying kapok (Ceiba pentandra), Silva et al. (2008) reported that liming favored all the evaluated characteristics except for $\mathrm{R} / \mathrm{S}$ ratio. The same tendency was observed for $D$. nigra in this study, and the above-mentioned author comments that it can be assumed that the changes caused by liming do not affect root or shoot tissues differently.
A higher DQI for D. nigra was found in the limestone dose in elevating base saturation to $53.8 \%$. Souza et al. (2010) found optimal DQI values in fedegoso (Senna macranthera) at baseline saturation of $70 \%$, much higher than that of this study. On the other hand, Cruz et al. (2004) reported pink ipê (Tabebuia impetiginosa) seedlings with the best DQI for increasing base saturation, similar to that obtained in this study.

Therefore, limestone doses aiming to reach base saturation of $53.8 \%$ for D. nigra (which is equivalent 
to 735 kilos of limestone per hectare in the soil) obtained seedlings with better quality indexes. In this study, ideal $\mathrm{V}(\%)$ results were found between 48 and 54, which are different from those found by Bernardino et al. (2007) and Gonçalves et al. (2014), who found no response to liming of $D$. nigra in dystrophic Latosol, leading them to conclude that there is no need for liming for this species under these conditions. The explanation for this fact is possibly in the genetic material of origin, which in the case of this study came from a park and a reserve where there is greater conservation/genetic variability. Several germination studies have obtained results showing that seeds from different places may present different behaviors when submitted to the same treatments, as in the case with Ladeia et al. (2012) in studying Pseudobombax longiflorum.

Diameter, height, dry matter of the shoot and root, total dry matter and DQI presented increasing
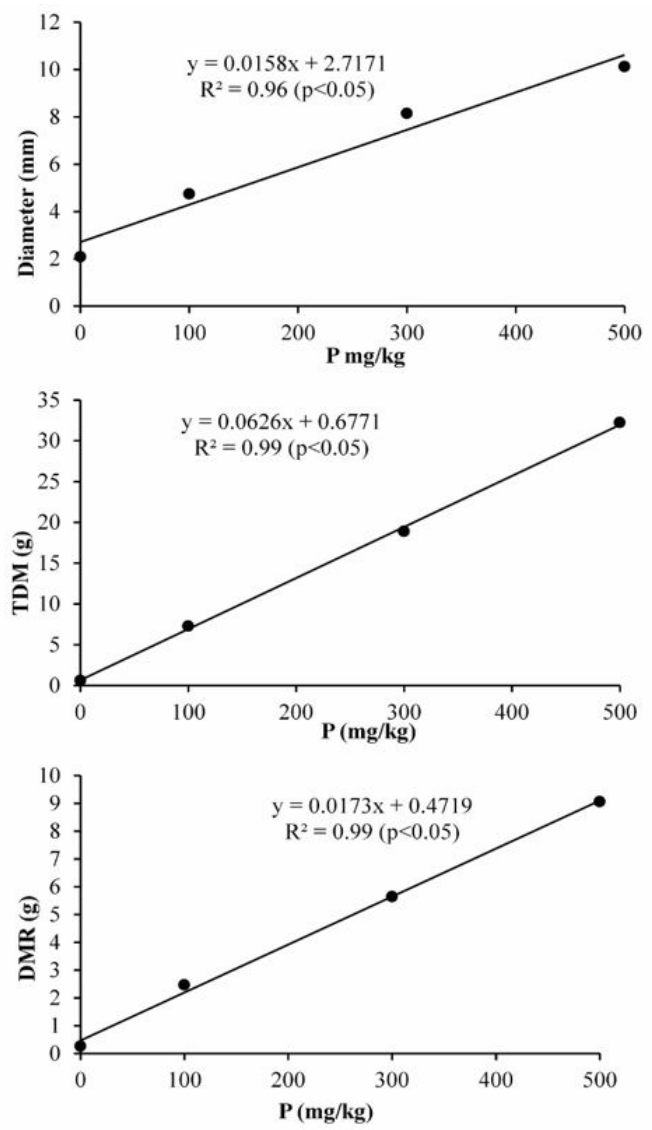

linear behavior in response of the phosphorus doses. Thus, the tested dose of $500 \mathrm{mg} \mathrm{kg}^{-1}$ presented the best performance in the seedlings (Figure 2). Cruz et al. (2010) found optimal doses of $416.23 \mathrm{mg} \mathrm{kg}^{-1}$ of phosphorus in Dystrophic Red Latosol/typic haplustox soil for Senna macranthera, which was inferior to the value found in this study. This indicates that some species require more phosphorus than others to develop. Phosphorus in the plant stimulates root growth and ensures vigorous growth (Malavolta et al., 1997), as observed in this study. Chaves \& Borges (2005) also found increasing linear values for $D$. nigra not inoculated with mycorrhizae. Santos et al. (2008) reported that pioneer and climax species showed linear growth up to a dose of $800 \mathrm{mg} \mathrm{kg}^{-1}$ of $\mathrm{P}$, being responsive to phosphorus application.

The species studied here was characterized by Pacheco et al. (2013) as late secondary to climax. However, the species under the conditions of the
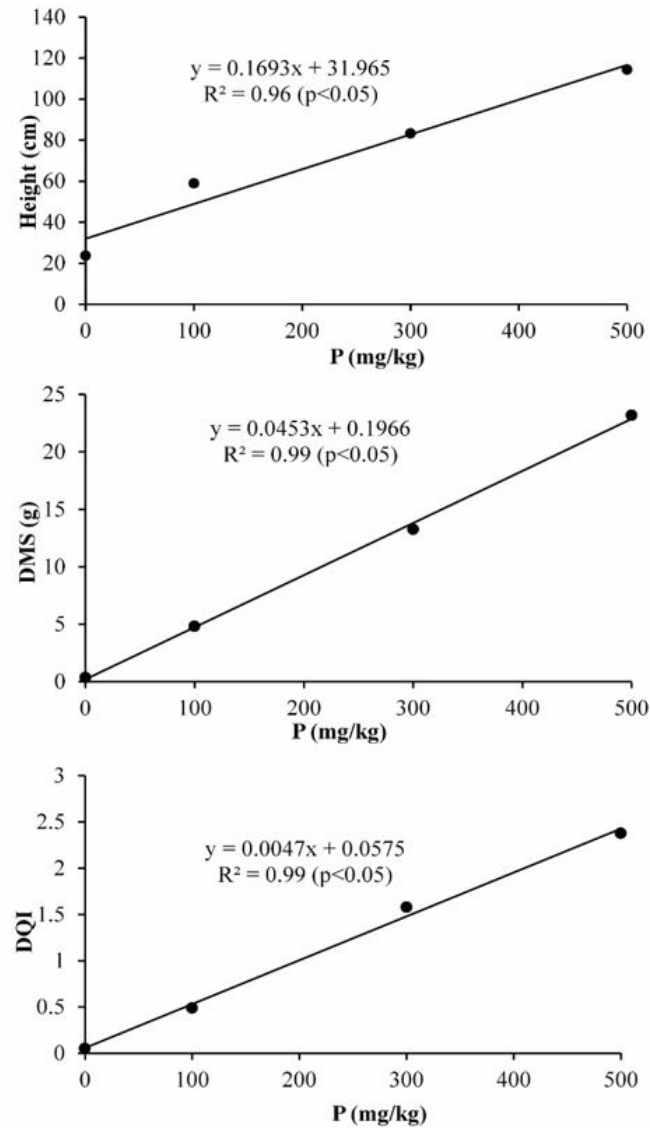

Figure 2. Diameter, height, total dry matter, dry matter of the shoot and roots (TDM, DMS, DMR) and DQI for D. nigra seedlings of 240 days under different phosphorus doses. 
present study were observed to act more like a pioneer species, presenting fast growth and linear response to phosphorus. According to Resende et al. (1999), pioneer species showed better results at optimal doses among species of different successional groups, being above $500 \mathrm{mg} \mathrm{kg}^{-1}$ for most of the species tested. On the other hand, climax species do not tend to present responses to fertilization. This is equivalent, for example, to the similar growth found by Gonçalves et al. (2008) for Anadenanthera macrocarpa in a Dystrophic Red Latosol/typic haplustox soil.

The Dickson quality index of seedlings for plants submitted to different phosphorus doses (Figure 2) also showed linear growth for D. nigra seedlings, and since the highest DQI value produces the best quality seedlings, the dose of $500 \mathrm{mg} \mathrm{kg}^{-1}$ presented the best results in this case. Cruz et al. (2011) also found increasing DQI values in canafistula (Peltophorum dubium) seedlings. The best results however, were found for the dose of $600 \mathrm{mg} \mathrm{kg}^{-1}$ of phosphorus for Dystrophic Red Latosol/typic haplustox soil.

The linear characteristic of the biometric parameters in relation to the phosphorus doses in the soil being studied is related to the adsorption of $\mathrm{P}$ in the soil, considering that it has high clay content. Chaves et al. (2007) concluded that the soil attributes that positively influenced phosphorus adsorption capacity were organic matter, base saturation and clay content, while adsorption energy was negatively influenced by these attributes.

The root/shoot ratio for D. nigra showed that the plant invested more in shoot growth than root growth under higher phosphorus doses (Figure 3).

According to Grant et al. (2001) and similar to what was observed in this study, the root-shoot ratio of the plant increases when there is phosphorus deficiency at the beginning of its development. This means that the reduction in growth due to phosphorus deficiency is generally higher in the shoot part of the plant than in the roots, thus allowing for at least maintaining root growth in order to find and extract more phosphorus from the soil. By contrast, there is no need to promote root growth when the availability of this nutrient is high since the phosphorus supply is facilitated by higher doses. Therefore, plants do not need to invest as much in root growth to obtain this nutrient and can instead invest in shoot growth, causing the root/shoot ratio to decrease.

\subsection{Nutrition}

\subsubsection{Effect of different liming on $\mathrm{Ca}, \mathrm{Mg}$ and $P$ content and accumulation}

The increase in the base saturation did not affect the phosphorus content in the plant shoots, while the accumulation of nutrients in the plant was significant (Figure 4) considering that there was a difference in shoot dry mass between the treatments (Figure 1). The soil analysis of the experiment (Table 1) shows that liming did not affect phosphorus availability in the soil.

Adding limestone provides $\mathrm{Ca}$ and $\mathrm{Mg}$ in addition to raising soil $\mathrm{pH}$, thus increasing the availability of these nutrients for crop uptake (Raij, 1991). As expected, the increase in base saturation favored an increase of $\mathrm{Ca}$ and $\mathrm{Mg}$ content in the shoot, and also presented increased linear behavior in relation to the increase in liming levels (Figure 4). Favare et al. (2012) found similar responses for $\mathrm{P}$ (without response), as well as for $\mathrm{Ca}$ and $\mathrm{Mg}$ with linear responses.

Nutrient accumulation in the shoot showed quadratic behavior directly influenced by the shoot dry mass.

\subsubsection{Effect of phosphorus doses on the content and accumulation of $\mathrm{Ca}, \mathrm{Mg}$ and $\mathrm{P}$}

The phosphorus levels in the shoot presented quadratic behavior. The maximum content point of this nutrient was for the dose of $27 \mathrm{mg} \mathrm{kg}^{-1}$ with an estimated level of $1.34 \mathrm{~g} \mathrm{~kg}^{-1}$ (Figure 5).

The $\mathrm{Ca}$ and $\mathrm{Mg}$ levels observed indicate higher values in the treatments without phosphorus application. This may be due to a higher concentration of these nutrients from the low shoot dry mass of the treated plants $(0.36 \mathrm{~g})$.

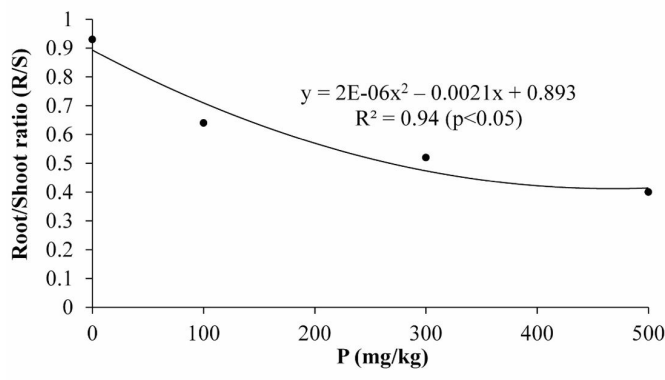

Figure 3. Root/shoot ratio (R/S) for D. nigra of 240 days under phosphorus doses. 

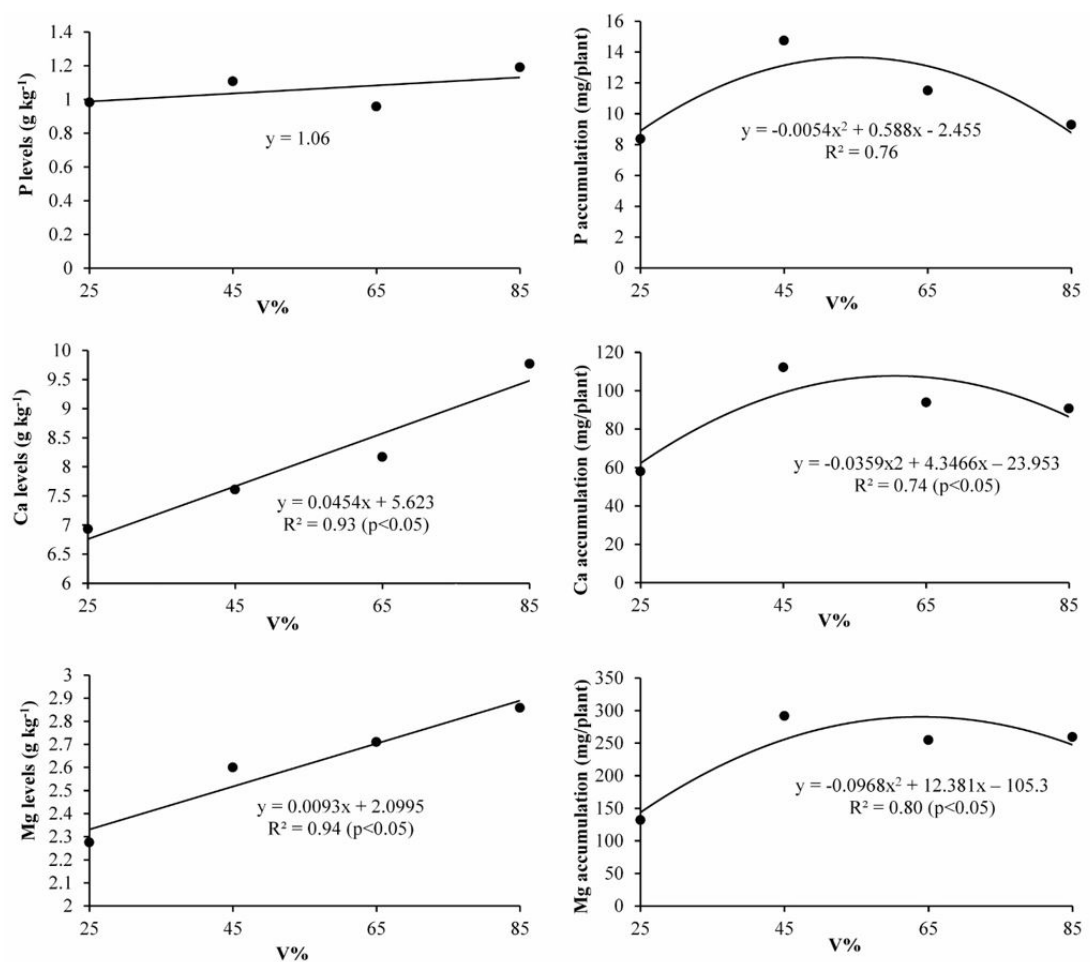

Figure 4. Calcium, magnesium and phosphorus levels and accumulation in D. nigra seedling shoots under different base saturations.
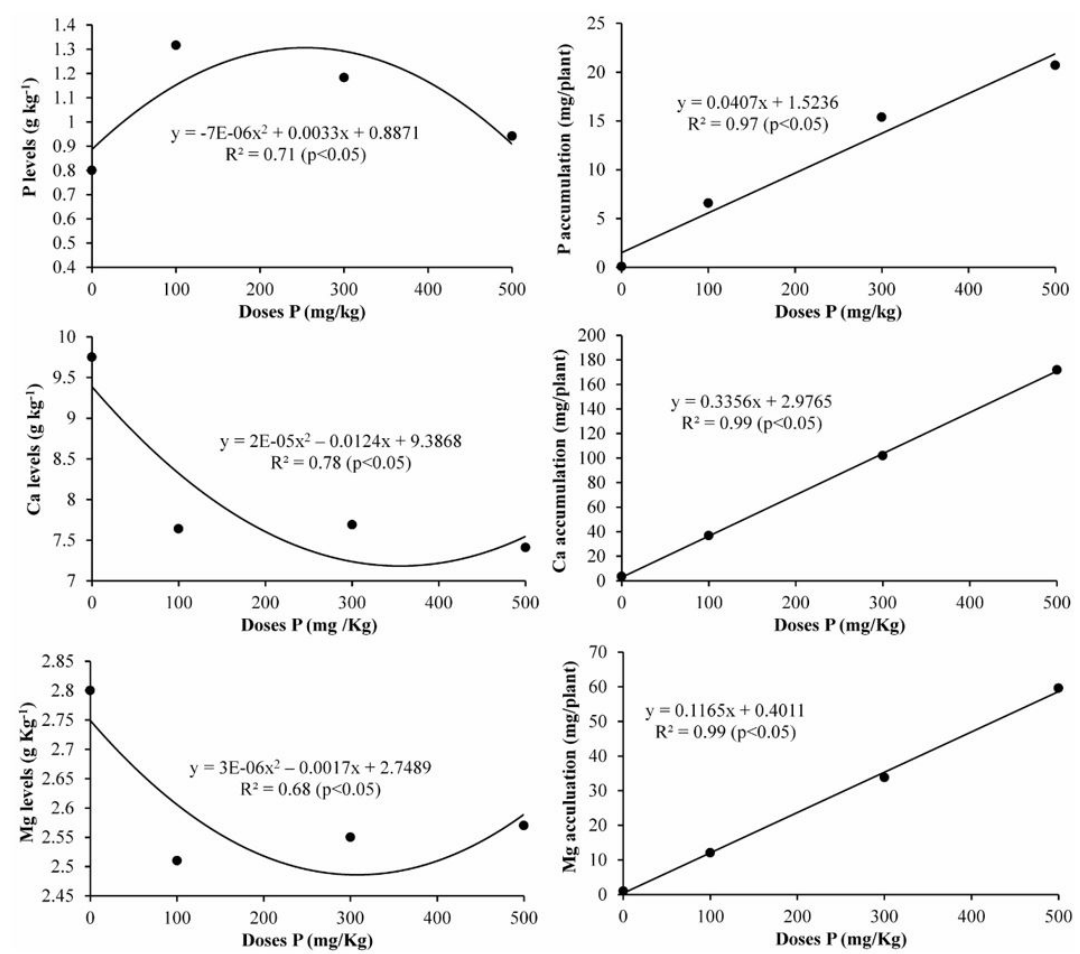

Figure 5. Calcium, magnesium and phosphorus levels and accumulation in D. nigra seedling shoots under different phosphorus doses. 
On the other hand, $\mathrm{P}, \mathrm{Ca}$ and $\mathrm{Mg}$ accumulation in the shoot were observed in a linear manner, presenting an increase up to the dose of $500 \mathrm{mg} \mathrm{kg}^{-1}$ as the phosphorus doses increased. The linear growth behavior presented by the phosphorus was the same for the accumulation of nutrients, where the greater the growth, the greater the accumulation in the plant.

\section{CONCLUSION}

Liming promoted a positive effect in D. nigra, with the best results found for base saturations between 48.07 and $54.76 \%$.

Phosphorus doses showed linear growth for all these variables, and the dose that promoted the best result was the maximum dose used of $500 \mathrm{mg} \mathrm{kg}^{-1}$.

Liming affects $\mathrm{Ca}$ and $\mathrm{Mg}$ content as well as $\mathrm{P}, \mathrm{Ca}$ and $\mathrm{Mg}$ accumulation in D. nigra plants. $\mathrm{P}$ doses affect both the content and accumulation of $\mathrm{P}, \mathrm{Ca}$ and $\mathrm{Mg}$ in D. nigra plants.

\section{ACKNOWLEDGEMENTS}

The authors are grateful to the Federal University of Lavras (UFLA) and to the Federal Institute of Goiano-Rio Verde (IFGoiano), where the first author is employed, for the support with the translation of the manuscript.

\section{SUBMISSION STATUS}

Received: 9 oct., 2017

Accepted: 26 oct., 2017

\section{CORRESPONDENCE TO}

\section{Leandro Carlos}

Programa de Pós-graduação em Ciências Agrárias, Departamento de Agronomia, Instituto Federal Goiano - IFGoiano, Rodovia Sul Goiana, Km 01, Zona Rural, CP 66, CEP 75901-970, Rio Verde, GO, Brasil e-mail: leandro.carlos@ifgoiano.edu.br

\section{FINANCIAL SUPPORT}

National Council for Scientific and Technological Development $(\mathrm{CNPq})$ and Coordination for the Improvement of Higher Education Personnel (CAPES).

\section{REFERENCES}

Andrade ACS, Pereira TS, Fernandes MJ, Cruz APM, Carvalho ASR. Substrato, temperatura de germinação e desenvolvimento pós-seminal de sementes de Dalbergia nigra. Pesquisa Agropecuária Brasileira 2006; 41(3): 517523. http://dx.doi.org/10.1590/S0100-204X2006000300020.

Bernardino DCS, Paiva HN, Neves JCL, Gomes JM, Marques VB. Influência da saturação por bases e da relação Ca: $\mathrm{Mg}$ do substrato sobre o crescimento inicial de jacarandá da Bahia (Dalbergia nigra) Vell. FR. All. Ex Benth). Revista Árvore 2007; 31(4): 567-573. http://dx.doi.org/10.1590/ S0100-67622007000400001.

Carlos LC, Venturin N, Farias ES, Venturin RP, Macedo RLG. Growth and mineral nutrition in seedlings of jacarandá-da-bahia subjected to nutrient deprivation. Floresta 2015; 45(1): 107-116. http://dx.doi.org/10.5380/ rf.v45i1.34312.

Carvalho PER. Espécies arbóreas brasileiras. Brasília: EMBRAPA Informação Tecnológica; Colombo: Embrapa Florestas; 2003.

Chaves LFC, Borges CG. Eficiência micorrízica na produção de mudas de jacarandá-da-bahia cultivadas em diferentes doses de fósforo. Acta Scientiarum. Agronomy 2005; 27(4): 587-594. http://dx.doi.org/10.4025/actasciagron.v27i4.1303.

Chaves LHG, Chaves IB, Mendes JS. Adsorção de fósforo em materiais de Latossolo e Argissolo. Revista Caatinga 2007; 20(3): 104-111.

Cruz CAF, Cunha ACMCM, Paiva HN, Neves JCL. Efeito de macronutrientes sobre o crescimento e qualidade de mudas de canafístula cultivadas em Latossolo VermelhoAmarelo distrófico. Revista Árvore 2011; 35(5): 983-995. http://dx.doi.org/10.1590/S0100-67622011000600004.

Cruz CAF, Paiva HN, Gomes KCO, Guerrero CRA. Efeito de diferentes níveis de saturação por bases no desenvolvimento e qualidade de mudas de ipê-roxo (Tabebuia impetiginosa (Mart.) Standley. Scientia Forestalis 2004; 66(1): 100-107.

Cruz CAF, Paiva HN, Neves JCL, Cunha ACMCM. Resposta de mudas de Senna macranthera (Dc. Ex collad.) H.S. Irwin \& Barnaby (Fedegoso) cultivadas em Latossolo vermelho-amarelo distrófico e macronutrientes. Revista Árvore 2010; 34(1): 13-24. http://dx.doi.org/10.1590/ S0100-67622010000100002.

Dickson A, Leaf A, Hosner JF. Quality appraisal of white spruce and white pine seedling stock in nurseries. Forestry Chronicle 1960; 36(1): 10-13. http://dx.doi.org/10.5558/ tfc36010-1.

Empresa Brasileira de Pesquisa Agropecuária - EMBRAPA. Centro Nacional de Pesquisa de Solos. Ministério da Agricultura e do Abastecimento. Manual de métodos de análise de solo. 2. ed. Rio de Janeiro; 1997.

Favare LG, Guerrini IA, Backes C. Níveis crescentes de saturação por bases e desenvolvimento inicial de Teca 
em um latossolo de textura média. Ciência Florestal 2012; 35(4): 693-702.

Fernandes LA, Furtini AE No, Fonseca FC, Vale FR. Crescimento inicial, níveis críticos de fósforo e frações fosfatadas em espécies florestais. Pesquisa Agropecuária Brasileira 2000; 35(6): 1191-1198. http://dx.doi.org/10.1590/ S0100-204X2000000600016.

Ferreira DF. Sisvar: a computer statistical analysis system. Ciência e Agrotecnologia 2011; 35(6): 1039-1042. http:// dx.doi.org/10.1590/S1413-70542011000600001.

Furtini AE No, Resende AV, Vale FR, Faquin V, Fernandes LA. Acidez do solo, crescimento e nutrição mineral de algumas espécies arbóreas, na fase de muda. Cerne 1999;5(2):1-12.

Gomes FP. Curso de estatística experimental. 2. ed. São Paulo: Nobel; 1985.

Gomes KCO, Paiva HN, Neves JCL, Barros NF, Silva SR. Crescimento de mudas de garapa em resposta a calagem e ao fósforo. Revista Árvore 2008; 32(3): 387-394. http:// dx.doi.org/10.1590/S0100-67622008000300001.

Gonçalves EO, Paiva HN, Neves JCL, Gomes JM. Crescimento de mudas de angico-vermelho (Anadenanthera macrocarpa (Benth.) Brenan) sob diferentes doses de macronutrientes. Revista Árvore 2008; 32(6): 1029-1040. http://dx.doi. org/10.1590/S0100-67622008000600008.

Gonçalves EO, Paiva HN, Neves JC, Klippel VH, Caldeira MVW. Crescimento de Dalbergia nigra (Vell.) Allemão ex Benth sob diferentes doses de cálcio, magnésio e enxofre. Revista Árvore 2014; 38(2): 251-260. http:// dx.doi.org/10.1590/S0100-67622014000200005.

Grant CA, Flaten DN, Tomasiewicz DJ, Sheppard SC. A importância do fósforo no desenvolvimento inicial da planta. Informações Agronômicas 2001; 95: 1-5.

Ladeia ES, Coelho MF, Azevedo RAB, Albuquerque MCF. Procedência do fruto e substratos na germinação de sementes de Pseudobombax longiflorum (Mart. et Zucc.) A. Robyns. Pesquisa Agropecuária Tropical 2012; 42(2): 174180. http://dx.doi.org/10.1590/S1983-40632012000200009.

Macedo ST, Teixeira PC. Calagem e adubação fosfatada para formação de mudas de araçá-boi. Acta Amazonica 2012; 42(3): 405-412. http://dx.doi.org/10.1590/S004459672012000300013.
Malavolta E, Vitti GC, Oliveira SA. Avaliação do estado nutricional das plantas: princípios e aplicações. 2. ed. Piracicaba: Potafos; 1997.

Mann EN, Furtini AE No, Resende AV, Vale FR, Fonseca FC. Calagem e crescimento de espécies florestais. In: Anais da Reunião Brasileira de Fertilidade do Solo e Nutrição de Plantas; 1996; Manaus. Manaus: Ed. da Universidade do Amazonas; 1996. p. 240-241.

Pacheco FV, Pereira CR, Silva RL, Alvarenga ICA. Crescimento inicial de Dalbergia nigra (Vell.) Allemão ex. Benth. (Fabaceae) e Chorisia speciosa A.St.-Hil (Malvaceae) sob diferentes níveis de sombreamento. Revista Árvore 2013; 37(5): 945-953. http://dx.doi.org/10.1590/S010067622013000500017

Raij B van. Fertilidade do solo e adubação. São Paulo: CERES/POTAFOS; 1991.

Resende AV, Furtini AE No, Muniz JÁ, Curi N, Faquin V. Crescimento inicial de espécies florestais de diferentes grupos sucessionais em resposta a doses de fósforo. Pesquisa Agropecuária Brasileira 1999; 34(11): 2071-2081. http:// dx.doi.org/10.1590/S0100-204X1999001100014.

Santos JZL, Resende AV, Furtini AE No, Corte EF. Crescimento, acúmulo de fósforo e frações fosfatadas em mudas de sete espécies arbóreas nativas. Revista Árvore 2008; 32(5): 799-807. http://dx.doi.org/10.1590/S010067622008000500003 .

Silva A, Tucci CAF, Lima HN, Souza PA, Venturin N. Efeitos de doses crescentes de calcário na produção de mudas de sumaúma (Ceiba pentandra L. Gaertn). Floresta 2008; 38(1): 295-302.

Silva TAF, Tucci CAF, Santos JZL, Batista IMP, Miranda JF, Souza MM. Calagem e adubação fofatada para a produção de mudas de Swietenia macrophilla. Floresta 2011; 41(3): 459-470. http://dx.doi.org/10.5380/rf.v41i3.23992.

Souza PH, Paiva HN, Neves JSL, Gomes JM, Marques LS. Crescimento e qualidade de mudas de Senna macranthera (Collad.) Irwin et Barn. em resposta à calagem. Revista Árvore 2010; 34(2): 233-240. http://dx.doi.org/10.1590/ S0100-67622010000200005.

Tucci CAF, Lima HN, Gama AS, Costa HS, Souza PA. Efeitos de doses crescentes de calcário em solo Latossolo Amarelo na produção de mudas de pau-de-balsa (Ochroma lagopus sw., Bombacaceae). Acta Amazonica 2010; 40(3): 543-548. http://dx.doi.org/10.1590/S0044-59672010000300013. 